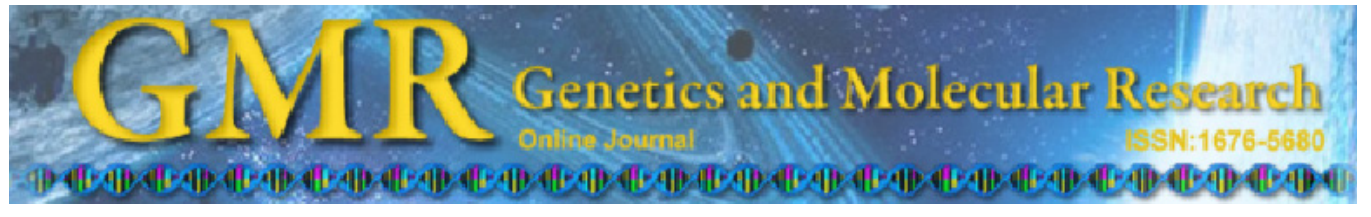

\title{
Isolation of high quality and polysaccharide-free DNA from leaves of Dimorphandra mollis (Leguminosae), a tree from the Brazilian Cerrado
}

\author{
H.A.V. Souza, L.A.C. Muller, R.L. Brandão and M.B. Lovato \\ Departamento de Biologia Geral, Instituto de Ciências Biológicas, \\ Universidade Federal de Minas Gerais, Belo Horizonte, MG, Brasil \\ Corresponding author: M.B. Lovato \\ E-mail: lovatomb@icb.ufmg.br
}

Genet. Mol. Res. 11 (1): 756-764 (2012)

Received September 28, 2011

Accepted January 11, 2012

Published March 22, 2012

DOI http://dx.doi.org/10.4238/2012.March.22.6

\begin{abstract}
Dimorphandra mollis (Leguminosae), known as faveiro and fava d'anta, is a tree that is widely distributed throughout the Brazilian Cerrado (a savanna-like biome). This species is economically valuable and has been extensively exploited because its fruits contain the flavonoid rutin, which is used to produce medications for human circulatory diseases. Knowledge about its genetic diversity is needed to guide decisions about the conservation and rational use of this species in order to maintain its diversity. DNA extraction is an essential step for obtaining good results in a molecular analysis. However, DNA isolation from plants is usually compromised by excessive contamination by secondary metabolites. DNA extraction of $D$. mollis, mainly from mature leaves, results in a highly viscous mass that is difficult to handle and use in techniques that require pure DNA. We tested four protocols for plant DNA extraction that can be used to minimize problems such as contamination by polysaccharides, which is more pronounced in material from mature leaves. The protocol that produced the best DNA quality initially utilizes a sorbitol buffer to remove mucilaginous polysaccharides. The macerated leaf material is washed with this buffer until there is no visible mucilage in the sample. This protocol is adequate
\end{abstract}


for DNA extraction both from young and mature leaves, and could be useful not only for $D$. mollis but also for other species that have high levels of polysaccharide contamination during the extraction process.

Key words: Cerrado; Dimorphandra mollis; Secondary metabolites; DNA extraction; High-quality DNA; Polysaccharide-free DNA

\section{INTRODUCTION}

Dimorphandra mollis Benth. is a tree widely distributed in the Cerrado, the second largest biome in Brazil, which is considered a hotspot for global conservation because of its diversity, richness of endemic species, and threatened status (Myers et al., 2000). D. mollis is a medicinal plant of high economic value that has been extensively exploited in recent years, mainly because its fruits contain the flavonoid rutin. Rutin has antioxidant, antiviral, antitumoral, and anti-inflammatory properties (Féres et al., 2006), and is widely used to produce medications for human circulatory diseases (Gomes and Gomes, 2000). Studies indicate that this species also has potential for use in the food industry because its seeds contain a high amount of galactomannan, which can be used as a thickener, stabilizer, and gelling agent (Panegassi et al., 2000). Considering the increasing destruction of the Cerrado due to agricultural activities, and the unsustainable exploitation of D. mollis fruits, this species may be threatened, and knowledge about its genetic diversity is needed to help guide important decisions about its conservation and rational use.

Most genetic diversity studies use molecular tools, which are mainly based on polymerase chain reaction (PCR) that requires good-quality DNA to obtain satisfactory results. However, reports about difficulties in isolating good-quality DNA are common in plants, especially in taxa from the Cerrado biome (Novaes et al., 2009; Silva, 2010; Moreira and Oliveira, 2011). Leaf tissues of different plant species have varying levels of polysaccharides, polyphenols, and other secondary metabolites that hinder the process of DNA purification and its use in molecular studies (Khanuja et al., 1999). These compounds bind tightly to nucleic acids during the isolation of DNA and interfere with subsequent reactions.

The utilization of fresh and young leaf material is ideal to obtain good-quality DNA (Sytsma et al., 1993, Moreira and Oliveira, 2011). Mature leaves contain higher quantities of polyphenols, tannins, and polysaccharides (Porebski et al., 1997), which makes it very difficult to isolate DNA of good quality. However, it is not always possible to find young leaves on sampled individuals, mainly in species from the Cerrado, because most of them are deciduous and only have young leaves for a short period of the year (such as D. mollis). DNA extraction from mature leaves of $D$. mollis by the traditional method described by Doyle and Doyle (1987) results in a highly viscous mass that does not amplify well in PCR. This viscous aspect of DNA solution has been attributed to contamination by polysaccharides (Porebski et al., 1997; Tel-Zur et al., 1999). Contamination by polysaccharides is notably problematic (Scott and Playford, 1996) and prevents the use of DNA in molecular techniques. The difficulty in obtaining DNA free of contaminants from mature leaves in D. mollis has already been reported (Moreira and Oliveira, 2011).

In this study, we showed the results of tests from several DNA extraction protocols that were made to overcome the problems that mainly arise from polysaccharide contamina- 
tion. We report a highly effective method for high-quality DNA isolation from young and mature leave of $D$. mollis.

\section{MATERIAL AND METHODS}

\section{Plant material}

DNA from mature leaves of 8 D. mollis individuals was extracted using 4 protocols, A to D (Jobes et al., 1995; Barnwell et al., 1998; Mogg and Bond, 2003; Russell et al., 2010), which have been described as being efficient for isolating good-quality DNA from samples with large quantities of secondary compounds. The traditional protocol for DNA extraction described by Doyle and Doyle (1987) was tested, but it has not been described because it did not produce good results for mature leaves of $D$. mollis. Its use for DNA extraction from young leaves of $D$. mollis has been described (Moreira and Oliveira, 2011). Furthermore, DNA from young leaves of 6 individuals was extracted with the protocol described by Russell et al. (2010) with a few modifications. Fresh leaves were collected and stored in plastic bags, within a box with ice, until they arrived at the laboratory where they were stored at $-20^{\circ} \mathrm{C}$ until extraction.

\section{Testing DNA extraction protocols}

For DNA extraction, we used $100 \mathrm{mg}$ leaves from each sample in all protocols, with the exception of the Mogg and Bond (2003) protocol where $1 \mathrm{~cm}^{2}$ leaves was used. The samples were ground in liquid nitrogen immediately before the procedure. The equipment and materials used in all protocols were: 1) mortar and pestle; 2) 1.5 - and $2.0-\mathrm{mL}$ microcentrifuge tubes; 3) liquid nitrogen; 4) water bath $\left(65^{\circ} \mathrm{C}\right)$, and 5) centrifuge and rotor capable of 14,000 $\operatorname{rpm}(17,746 \mathrm{~g})$. Below are the brief explanations of protocols A, B, and C, and a detailed explanation of protocol D.

\section{DNA extraction protocol A (Jobes et al., 1995)}

This protocol was described as an efficient method for removing polyphenols, polysaccharides, and RNA. It utilizes SDS as a detergent, PVP for binding the phenolic compounds, proteinase $\mathrm{K}$ for removing proteins, potassium acetate and isopropanol for precipitation, a high-molar concentration of sodium chloride for inhibiting coprecipitation of polysaccharides and DNA, and an improved method for removing RNA by selective precipitation with lithium chloride.

\section{DNA extraction protocol B (Mogg and Bond, 2003)}

This method was described as a cheap, reliable, and rapid technique for extracting high-quality DNA from plants. The method utilizes SDS as a detergent, proteinase $\mathrm{K}$ for removing proteins, RNase for removing RNA, and alcohol/salt (isopropanol $/ \mathrm{NaCl}$ ) precipitation for inhibiting coprecipitation of polysaccharides and DNA.

\section{DNA extraction protocol C (Barnwell et al., 1998)}

This method was described for the extraction of DNA from the highly mucilaginous 
succulent plant Sedum telephium. This species has gelling polysaccharides that coprecipitate with DNA, which creates the same problem as that for D. mollis. The method utilizes CTAB as a detergent, PVP for binding the phenolic compounds, and alcohol/salt precipitation (absolute ethanol $/ \mathrm{NaCl}$ ) for inhibiting coprecipitation of polysaccharides and DNA. In this method, the concentration of CTAB is increased with the goal of precipitating nucleic acids free from contamination by polysaccharides and polyphenols.

\section{DNA extraction protocol D (Russell et al., 2010, with a few modifications)}

This protocol is a modification of the protocols by Doyle and Doyle (1987), Li et al. (2007), and Tel-Zur et al. (1999). It initially utilizes a sorbitol buffer for removing mucilaginous polysaccharides, and tissue extraction with a CTAB buffer with a high salt concentration for suppressing coprecipitation of polysaccharides and DNA.

\section{Reagents and solutions}

1. Sorbitol buffer: $100 \mathrm{mM}$ Tris-HCl, $\mathrm{pH}$ 8.0, $0.35 \mathrm{M}$ sorbitol, $5 \mathrm{mM}$ EDTA, pH 8.0, stored at $4{ }^{\circ} \mathrm{C}, 1 \%$ PVP-40 with $1 \%$ 2-mercaptoethanol (added just before use).

2. High-salt CTAB extraction buffer: $100 \mathrm{mM}$ Tris- $\mathrm{HCl}, \mathrm{pH} 8.0,3 \mathrm{M} \mathrm{NaCl}, 3 \%$ CTAB, $20 \mathrm{mM}$ EDTA, pH 8.0, preheated to $60^{\circ} \mathrm{C}$, and $1 \%$ PVP-40 and $0.2 \%$ 2-mercaptoethanol (added just before use) and sarkosyl (30\% aqueous solution).

3. Chloroform:isoamyl alcohol (CIA, 24:1 v/v).

4. Sodium acetate solution ( $3 \mathrm{M}$ adjusted to $\mathrm{pH} 5.2$ ).

5. Isopropanol (100\%).

6. Ethanol (70 and 100\%).

7. TE-RNase solution: $10 \mathrm{mM}$ Tris-HCl, $\mathrm{pH} 8.0,1 \mathrm{mM}$ EDTA, $\mathrm{pH} 8.0,10 \mathrm{mg} / \mathrm{mL}$ RNase.

\section{Protocol}

1. To each ground leaf sample, add $1 \mathrm{~mL}$ sorbitol buffer.

2. Centrifuge for $10 \mathrm{~min}$ at $5700 \mathrm{rpm}$. Discard the supernatant, dissolve the pellet in $1 \mathrm{~mL}$ sorbitol buffer, and repeat the sorbitol buffer cleaning until no visible mucilage layer is present in the sample pellet after centrifugation (usually 3 or 4 rounds, sometimes more).

3. To each sample, add $1 \mathrm{~mL}$ high-salt CTAB extraction buffer, and incubate samples for $1 \mathrm{~h}$ at $60^{\circ} \mathrm{C}$. Mix the samples with this buffer before the samples are placed in the bath. To facilitate mixing, place the tubes in the bath for $2 \mathrm{~min}$ at $60^{\circ} \mathrm{C}$.

4. Add $700 \mu \mathrm{L}$ CIA, mix gently for $20 \mathrm{~min}$, and then centrifuge for $10 \mathrm{~min}$ at 13,000 rpm.

5. Transfer the supernatant to a new tube, and add $1 / 10$ volume sodium acetate ( 3 $\mathrm{M}, \mathrm{pH}$ 5.2) and $2 / 3$ volume cold isopropanol. Mix gently, and incubate at $-20^{\circ} \mathrm{C}$ overnight.

6. Centrifuge for $30 \mathrm{~min}$. Wash the pellet twice with $500 \mu \mathrm{L} 70 \%$ ethanol and once with $500 \mu \mathrm{L} 100 \%$ ethanol, and centrifuge for $5 \mathrm{~min}$. 
7. Dry the DNA, and dissolve the pellet in 20-100 $\mu \mathrm{L}$ TE-RNase solution, varying according to the size of the pellet. Incubate for $2 \mathrm{~h}$ at $37^{\circ} \mathrm{C}$.

\section{Notes}

1. If DNA is extracted from silica-gel-dried leaves, use $50 \mathrm{mg}$ tissue.

2. The high-salt CTAB extraction buffer should be incubated at $60^{\circ} \mathrm{C}$ at the beginning of extraction to facilitate pipetting.

\section{DNA quantification and DNA quality evaluation}

DNA quantification was performed by spectrophotometry using an aliquot of $1 \mu \mathrm{L}$ total genomic DNA with the spectrophotometer NanoDrop ${ }^{\mathrm{TM}}$ (NanoDrop Technologies) according to manufacturer instructions. The concentration of DNA was obtained by absorbance at $260 \mathrm{~nm}$. The ratio of nucleic acids to proteins in the sample was evaluated by the ratio of the absorbance at 260 and $280 \mathrm{~nm}$ (A260/A280 ratio) (Sambrook and Russell, 2001). The presence and quality of DNA obtained by these protocols were also evaluated by electrophoresis on a $1 \%$ TAE agarose gel, stained with ethidium bromide, and viewed under UV light.

\section{DNA amplification}

DNA samples were assessed for successful PCR amplification with ISSR (inter-simple sequence repeats) primers. Amplification products were electrophoretically separated on $1.5 \%$ agarose gels with a $1 \mathrm{X}$ TAE buffer, stained with ethidium bromide, and photographed under UV light. A 100-bp DNA ladder was used to estimate the molecular size of the fragments. PCR conditions and cycles were the same as those used by Souza and Lovato (2010).

\section{RESULTS AND DISCUSSION}

Four protocols known to solve problems in DNA extraction from leaves producing high-quality DNA were tested to determine their efficiency, mainly from mature leaves of $D$. mollis. Three of these failed to produce a good quality and high quantity of DNA (Figure 1). The protocols described by Jobes et al. (1995), Mogg and Bond (2003), and Barnwell et al. (1998) produced DNA that was highly contaminated with secondary compounds, resulting in a highly viscous DNA solution that was difficult to handle and was usually brownish, indicating contamination by phenolic compounds (Moreira and Oliveira, 2011). The presence of polysaccharides was quite evident in the DNA extracted because it had a viscous aspect and glue-like texture (Tel-Zur et al., 1999). During DNA isolation, polysaccharides can coprecipitate with DNA after addition of alcohol, which forms highly viscous solutions (Do and Adams, 1991). Contamination by polysaccharides makes the DNA difficult to pipette and unamplifiable in PCR by inhibition of Taq polymerase activity (Fang et al., 1992). The amount of DNA obtained with these protocols was very low, and the quality was poor for most of the samples. Most of them had an A260/A280 ratio below the optimal limit of 1.8 (Sambrook and Russell, 2001). 

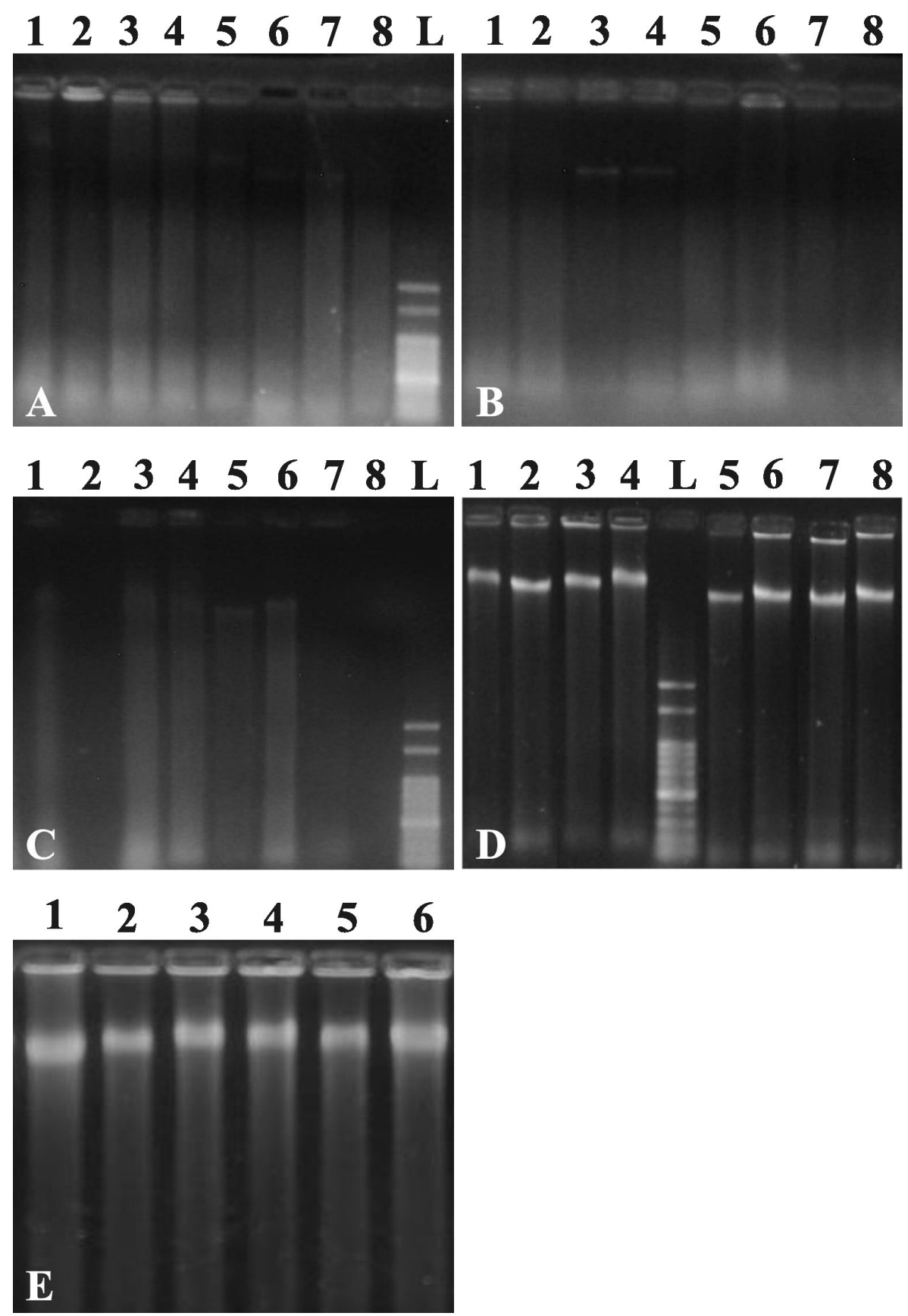

Figure 1. Total genomic DNA from mature (A, B, C, and D) and young leaves (E) of Dimorphandra mollis extracted by the following protocols: A. Jobes et al. (1995); B. Mogg and Bond (2003); C. Barnwell et al. (1998); and $\mathbf{D}$ and $\mathbf{E}$. Russell et al. (2010). Mature leaves are represented by lanes 1 to 8 in A, B, C and D. Young leaves are represented by lanes 1 to 6 in E. Lane $L=100$-bp ladder. 
Unlike all the protocols mentioned above, the method described by Russell et al. (2010) with a few modifications for DNA extraction of both mature and young leaves of $D$. mollis was successful, resulting in large amounts of high-quality DNA (Figure 1). The difficulty in extracting DNA from old leaves of D. mollis has already been described (Moreira and Oliveira, 2011); however, the methodology described by Russell et al. (2010) was very effective in overcoming the problems encountered even in the extraction from mature leaves of $D$. mollis. The amount of DNA obtained was very high ranging from approximately 1300 to 2360 $\mathrm{ng} / \mu \mathrm{L}$. The quality of the DNA was high for all samples, with $100 \%$ of them with an A260/ A280 ratio above the optimal limit of 1.8 (Sambrook and Russell, 2001). The DNA obtained was free of gelatinous substances, which usually coprecipitate with DNA, and was without proteins and phenols. The absence of phenolic compounds could be observed by the transparency of the DNA obtained. Cleaning the leaf tissue with the sorbitol buffer removed most of the polysaccharides and other contaminants that would otherwise hamper DNA extraction. Similar to the fresh leaves, the protocol described by Russell et al. (2010) with modifications also produced DNA of a high quality for silica-gel-dried leaves (data not shown).

PCR performed with DNA from mature leaves of $D$. mollis extracted with the protocol described by Russell et al. (2010) was successful in producing strong bands for all the samples tested for ISSR markers (Figure 2). Thus, the DNA obtained from mature leaves of D. mollis was pure enough to be suitable for PCR amplifications. Novaes et al. (2009) reported difficulty in amplifying DNA extracted from leaves of $D$. mollis. This problem was probably due to not using a suitable protocol for DNA extraction of the species.

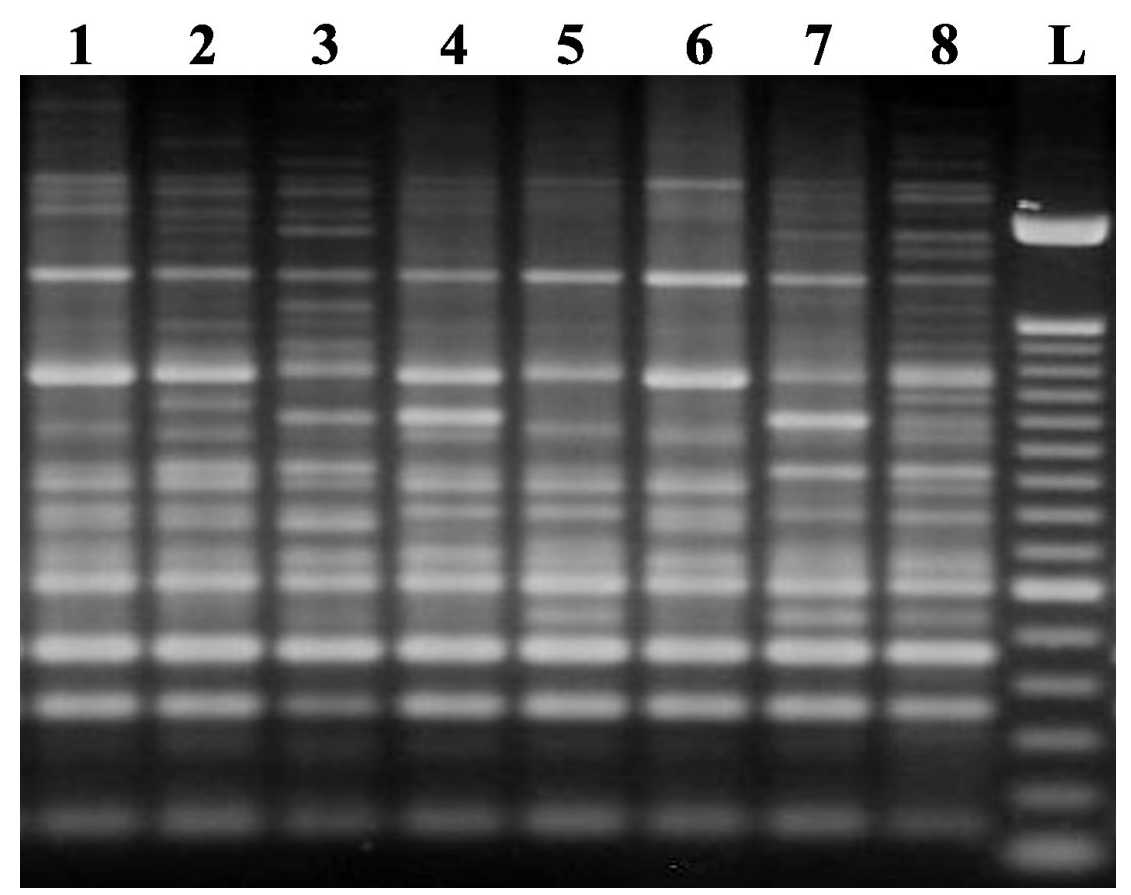

Figure 2. Amplification of ISSR markers from Dimorphandra mollis DNA extracted from mature leaves using the protocol described by Russell et al., 2010 (lanes 1 to 8 ). Lane $L=100$-bp ladder. 
The problems that arise in DNA extraction of plants are mainly due to contamination of DNA by secondary compounds that inhibit or even prevent their use in various types of analyses. In this paper, we present an extremely efficient protocol to isolate high-quality DNA from leaves of $D$. mollis, a species that has large amounts of polysaccharides in its leaves. This protocol could also be useful in other plant species in particular those from Cerrado that may have the same problems as $D$. mollis, exhibiting high polysaccharide contamination during the DNA extraction process.

\title{
ACKNOWLEDGMENTS
}

\author{
We thank FAPEMIG (\#APQ-01741-10) and CNPq (\#472423/2010-0) for the financial \\ support. H.A.V. Souza had a PhD fellowship from FAPEMIG.
}

\section{REFERENCES}

Barnwell P, Blanchard AN, Bryant JA and Smirnoff N (1998). Isolation of DNA from the highly mucilaginous succulent plant Sedum telephium. Plant Mol. Biol. Rep. 16: 133-138.

Do N and Adams RP (1991). A simple technique for removing plant polysaccharide contaminants from DNA. Biotechniques 10: $162-166$

Doyle JJ and Doyle JL (1987). A rapid DNA isolation procedure for small quantities of fresh leaf tissue. Phytoch. Bull. 19: 11-15.

Fang G, Hammar S and Grumet R (1992). A quick and inexpensive method for removing polysaccharides from plant genomic DNA. Biotechniques 13: 52-56.

Féres CA, Madalosso RC, Rocha OA, Leite JP, et al. (2006). Acute and chronic toxicological studies of Dimorphandra mollis in experimental animals. J. Ethnopharmacol. 108: 450-456.

Gomes LJ and Gomes MAO (2000). O extrativismo e biodiversidade: o caso da fava d'anta. Cienc. Hoje 27: 66-69.

Jobes DV, Hurley DL and Thien LB (1995). Plant DNA isolation: a method to efficiently remove polyphenolics, polysaccharides, and RNA. Taxon 44: 349-386.

Khanuja SPS, Shasany AK, Darokar MP and Kumar S (1999). Rapid isolation of DNA from dry and fresh samples of plants producing large amounts of secondary metabolites and essential oils. Plant Mol. Biol. Rep. 17: 1-7.

Li JT, Yang J, Chen DC, Zhang XL, et al. (2007). An optimized mini-preparation method to obtain high-quality genomic DNA from mature leaves of sunflower. Genet. Mol. Res. 6: 1064-1071.

Mogg RJ and Bond JM (2003). A cheap, reliable and rapid method of extracting high-quality DNA from plants. Mol. Ecol. Notes 3: 666-668.

Moreira PA and Oliveira DA (2011). Leaf age affects the quality of DNA extracted from Dimorphandra mollis (Fabaceae), a tropical tree species from the Cerrado region of Brazil. Genet. Mol. Res. 10: 353-358.

Myers N, Mittermeier RA, Mittermeier CG, da Fonseca GA, et al. (2000). Biodiversity hotspots for conservation priorities. Nature 403: 853-858.

Novaes RM, Rodrigues JG and Lovato MB (2009). An efficient protocol for tissue sampling and DNA isolation from the stem bark of Leguminosae trees. Genet. Mol. Res. 8: 86-96.

Panegassi VR, Serra GE and Buckeridge MS (2000). Seeds of faveiro (Dimorphandra mollis) as a potential source of galactomannan for the food industry. Ciênc. Tecnol. Aliment. 20: 406-415.

Porebski S, Bailey LG and Baum BR (1997). Modification of a CTAB DNA extraction protocol for plants containing high polysaccharide and polyphenol components. Plant Mol. Biol. Rep. 15: 8-15.

Russell A, Samuel R, Rupp B and Barfuss MHJ (2010). Phylogenetics and cytology of a pantropical orchid genus Polystachya (Polystachyinae, Vandeae, Orchidaceae): Evidence from plastid DNA sequence data. Taxon 59: 389404.

Sambrook J and Russell DW (2001). Molecular Cloning: A Laboratory Manual. Cold Spring Harbor Laboratory Press, New York

Scott KD and Playford J (1996). DNA extraction technique for PCR in rain forest plant species. Biotechniques 20: $974-$ 978.

Silva MN (2010). Extraction of genomic DNA from leaf tissues of mature native species of the Cerrado. Rev. Árvore 34: 
973-978.

Souza HAV and Lovato MB (2010). Genetic diversity of the critically endangered tree Dimorphandra wilsonii and the widespread in the Brazilian Cerrado Dimorphandra mollis: implications for conservation. Biochem. Syst. Ecol. 38: 49-56.

Sytsma K, Givnish TJ, Simt JF and Hahn WJ (1993). Collection and Storage of Land Plant Samples for Macromolecular Comparisons. In: Methods in Enzymology - Molecular Evolution: Producing the Biochemical Data (Zimmer EA, White TJ, Cann RL and Wilson AC, eds.). Academic Press, San Diego, 23-38.

Tel-Zur N, Abbo S, Myslabodski D and Mizrahi Y (1999). Modified CTAB procedure for DNA isolation from epiphytic cacti of the genera Hylocereus and Selenicereus (Cactaceae). Plant Mol. Biol. Rep. 17: 249-254. 